\title{
Ceramic Bearings for Use in Gas Turbine Engines
}

\author{
(AASA-TA-1CC2EE) CERALIC EEAEIXGS FOR USE N88-180C7 \\ IA GAS TUREINE ENEINES (NASA) 15 FCSCL 13 I \\ $\begin{array}{ll}\text { UnClas } \\ 03 / 37 & 0125890\end{array}$
}

Erwin V. Zaretsky

Lewis Research Center

Cleveland, Ohio

Prepared for the

33rd International Gas Turbine and Aeroengine Congress and Exposition sponsored by the American Society of Mechanical Engineers

Amsterdam, The Netherlands, June 5-9, 1988

\section{Nush}




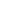




\title{
ORIGINAL PAGE IS \\ OF POOR QUALITY
}

\author{
CERAMIC BEARINGS FOR USE IN GAS TURBINE ENGINES \\ Erwin V. Zaretsky* \\ National Aeronautics and Space Administration \\ Lewis Research Center \\ Cleveland, Onio 44135
}

\footnotetext{
ABSTRACT

Three decades of research by U.S. industry and government laboratories have produced a vast array of data related to the use of ceramic rolling-element bearings and bearing components for aircraft gas turbine engines. Materials such as alumina, silicon carbide, titanium carbide, silicon nitride, and a crystallized glass ceramic have been investigated. $\vec{j}$ Roling-element endurance tests and andysis of full-
$\stackrel{m}{m}$ complement bearings have been performed. Materials and $m$ bearing design methods have continuously improved over the years. This paper reviews a wide range of data and andiyses with emphas is on how early NASA contributions as well as more recent data can enable the engineer or metallurgist to determine just where ceramic bearings are most applicable for gas turbines.

NOMENCLATURE

C dynamic load capacity, $N($ lb)

$E\left[\frac{1}{2}+\frac{Y_{S}\left(1-\delta_{c}^{2}\right)}{2 \gamma_{C}\left(1-\delta_{S}^{2}\right)}\right]$

e Weibull slope or modulus

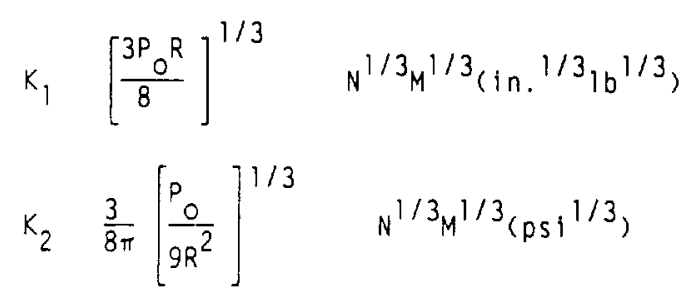

L life, hr, millions of inner-race revolutions or millions of stress cycles

*Fel low ASME.
}

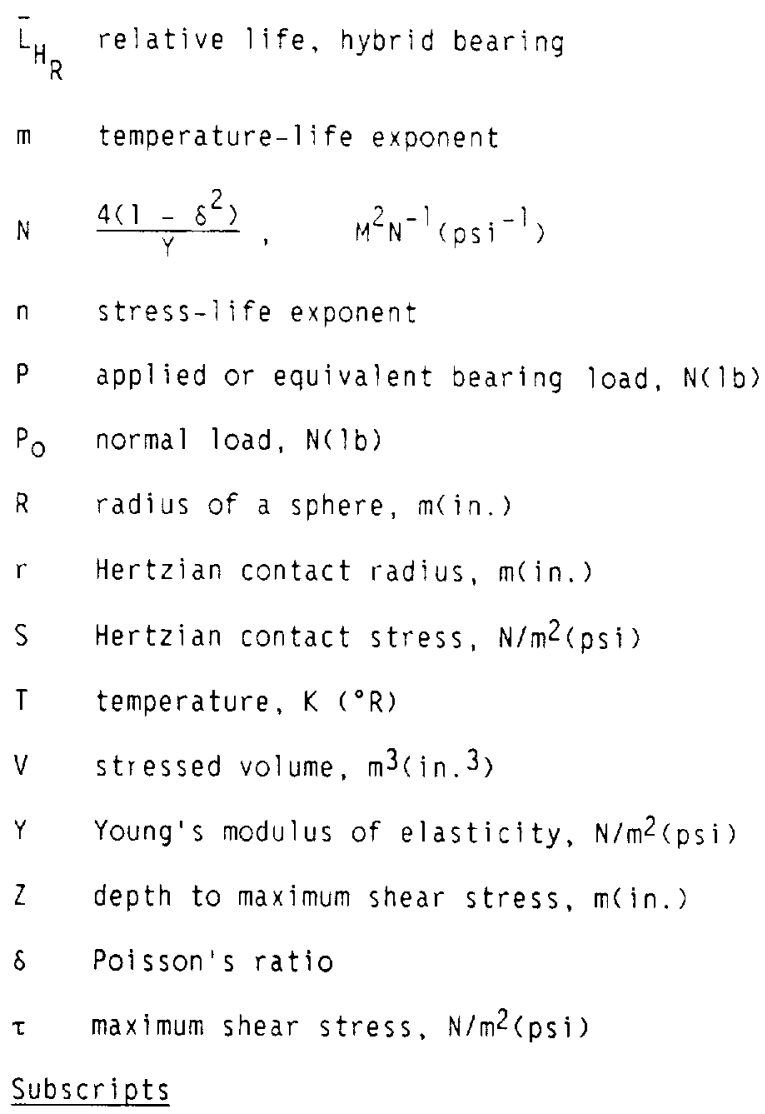


Geramic materials offer some cotentiai javantages ior rolling-element bearing components because of their :apability of operating over a wide temperazure range and their : ow density relative to rolling-element bearig steels. The low density of ceramics may make them ittractive as oall or roller materials for very highwesc cearings. This benefit is oue to the fact that -he fatigue life of very high-speed ball bearings can be recuced as a result of excessive centrifugal force in the calls and subsequent increased stress at the suter race (Harris, 1968). Lower mass balls can diminin this fatique life reduction.

Ceramic materials generally maintain their

strength and corrosion resistance over a range of temperatures much greater than typical rolling-element vearing steels. Taylor et al. (1963) was the first to evaluate hot-pressed silicon carbide and hot-pressed alumina for rolling-element bearings to temperatures aoove $811 \mathrm{~K}\left(1000^{\circ} \mathrm{F}\right)$.

A crystallized glass ceramic was examined in rolling-element fatigue by Carter and Zaretsky (1960) and Zaretsky and Anderson (1961) of NASA Lewis Research Center. The results of these early tests showed that the failure mode of ceramics was similar to that in bearing steels. That is, the fallure was cyclic dependent and apparently of subsurface origin, occurring at the depth of the maximum shear stress. The a li lure manifested itself as a spall that was itmited to the depth of the maximum shear stress and in diameter to the width of the contact zone. The life of the ceramic material was less than 10 percent that of a cypical rolling-element bearing steel under the same conditions of stress. However, the scatter in life (time to failure) was much less than that experienced by bearing steels. Appledoorn and Royle (1965) confirmed these results in a later study.

Parker et al. (1965) of NASA also conducted studies with three ceramics and one cermet for hightemperature, rolling-element bearing applications. The ceramic materials were hot-pressed and cold-pressed alumina, both 99 percent pure, and a two-phase sintered silicon carbide. Endurance tests were also conducted with the hot-pressed alumina to $1367 \mathrm{~K}\left(2000^{\circ} \mathrm{F}\right)$. The time to failure for the ceramics was found to have less scatter than for bearing steels. The mode of failure was a spall which was attributed to a surface condition rather than subsurface shear stresses. Hot-pressed alumina performed the best of the four materials. However, the life of this material was only 7 percent that of a typical bearing steel at the same condition of stress. It was concluded that the life of these refractory ceramic materials was related to the porosity, surface finish, and homogeneity of the material (Parker et al., 1965).

Baughman and Bamberger (1963) performed unlubricated high-temperature bearing studies to $922 \mathrm{~K}$ $\left(1200^{\circ} \mathrm{F}\right.$ ) in the rolling-contact (R-C) tester and fuli-scale needle bearings. They tested the following materials: Star-J and Stellite 25 (super alloys) and silicon carbide and alumina ceramics. The silicon carbide was shown to be the most wear resistant material. However, the silicon carbide material lacked homogeneity which resulted in nonuniform results.

In 1970, hot-pressed sli icon nitride was proposed for rolling-element bearings as well as for journal bearings (Dee, 1970). Rolling-element fatigue testing of hot-pressed silicon nitrlde has resulted in seemingly contradictory results. Poor results were obtained in the 1 imited tests reported in scott et al.
(1971) and Scott and Blackwell (1973). The results reported in Baumgartner (1973) and Baumgartner et al (1973) showed the rolling-element fatigue life of hotpressed silicon nitride to exceed that of a typical rolling-element bearing steel. Extrapolation of the experimental results of Parker and Zaretsky (1975) to contact loads which result in stress levels typical of those in rolling-element bearing applications indicate that hot-pressed silicon nitride running against steel may be expected to yield fatigue lives comparable to or greater than those of bearing quality steel running against steel.

Concurrent with the work of Dee (1970), scott et a). (1971), Scott and Blackwell (1973), Baumgartner (1973), Baumgartner et al. (1973), and Parker and Zaretsky (1975), hybrid bearings comprising silicon nitride rolling-elements and steel races were manufactured and tested (Baumgartner et al.. 1973; Baumgartner et al., 1976; Baumgartner and Cowley, 1975: Reddecliff and Valorl, 1976; and Mtner et al. 1981) as well as silicon nitride rolling-elements and rings (Baumgartner et al., 1973; Miner et al., 1981: Hosang, 1987; and Bailey, 1983).

In view of the aforementioned it is the objective of the work reported herein to summarize the data and analyses related to ceramic bearings for use in gas turbine englnes. Emphasis is placed on how early NASA contributions as well as more recent data can enable the engineer or metallurgist to determine just where ceramic bearings are most applicable for future gas turbine engines.

\section{EFFECT OF CONTACT STRESS}

It has long been established that the rollingelement fatigue $1 i f e, \bar{L}$, of a rolling element is inversely proportional to stress, $S$, to a power, $n$, that is,

$$
\bar{L} \sim s^{-n}
$$

For bearing steels the accepted value in the bearing industry for the stress-life exponent is 9 to 10 . However, varlations in this value have been noted and may be a function of material processing (Parker and Zaretsky, 1972a). A summary of the stress-life exponents for the ceramic and cermet materials tested for rolling-element bearing application which were compiled from Carter and Zaretsky (1960), Zaretsky and Anderson (1961), Parker et al. (1965), and Baumgartner et al. (1973) are summarized in Table ' $I$.

When steel and other metallic materials are tested at different stress levels, direct comparisons of fatigue lives can be made only by adjusting one of the lives using the proper stress-life exponent for that materlal (given in Table I), or by making a comparison on the basis of dynamic load capacity. The dynamic load capacity, contact load, and life are related by the equation (Lundberg and Palmgren, 1947; Lundberg and Palmgren, 1949; and Lundberg and Palmgren, 1952),

$$
c=P \sqrt[n]{E}
$$

where

C dynamic load capacity or load which will produce fallure of 10 percent of test specimen in 1 million stress cycles, $N(10)$

$P$ applied or equivalent bearing load, $N(I b)$ 
n exponent relating stress and life, determined experimentally

L life in millions of stress cycles which 90 percent of a group of specimens survive or within which time 10 percent fail

For steels, $n / 3$ is usually taken as 3 cbased on a stress-iife exponent of 9). The values of $n$ for each of the materials can be obtained from Table I. The relative dynamic capacities for each of the ceramic materials are then given based upon typical bearing steels. Knowing the dynamic capacity of an equivalent steel bearing, the value of the steel bearing can be multiolied by the relative dynamic capacity of the selected material from Table I. Using the resultant value, the applicable stress-life exponent, $n$, and the applied bearing load, $p$, in Eq. (1), an estimate of the ceramic bearing life, E, in millions of inner-race revolutions can be obtained.

There is conflicting data with regard to the life of the silicon nitride material. Figure l (Parker and Zaretsky, 1974) shows a comparison of life data for hot-pressed silicon nitride and for typical bearing steels, consumable-electrode vacuum melted (CVM) AISI 52100 and AISI M-50 (Parker and Zaretsky, 1972b) at a maximum Hertz stress of $5.52 \times 10^{9} \mathrm{~N} / \mathrm{m}^{2}$ (800 000 osi). The 10-percent fatigue life of the silicon nitride balls was approximately one-eighth that of the AISI $52100 \mathrm{bal} / \mathrm{s}$ and approximately one-fifth that of the AISI M-50 balls. Figure 2 (Baumgartner et al., 1973) snows results from the rolling-contact fatigue ( $R-C$ ) tester for silicon nitride and AISI M-50. These results show that the life of the AISI M-50 material was approximately one-eighth the life of the silicon nitride material at a maximum Hertz stress of $4.83 \times 10^{9} \mathrm{~N} / \mathrm{m}^{2}$ (700 $000 \mathrm{psi}$ ). However, the data for Baumgartner et al. (1973) and Parker and Zaretsky (1974) show a stress-1ife exponent, $n$, of 16.2 and 16 , respectively. Based upon both sets of data, the dynamic capacity (or load carrying ability) of the silicon nitride material would be significantly less than that of a typical bearing steel. This is shown in Table I where relative $C$ values have been calculated and compared to a bearing steel.

\section{EFFECT OF ELASTIC PROPERTIES}

The physical and thermal properties of ceramic and cermet materials considered for rolling-element bearing application are given in Table II. The properties are a compilation from (Carter and Zaretsky, 1960; Parker et a1., 1965; Parker and Zaretsky, 1974; Parker et al., :964a; Parker et al., 1964b; Sibley et al., 1960; and Bhushan and sibley, 1982). The elastic modulus of most ceramics is much greater than that of a bearing steel. Consequently, the resultant contact or Hertz stress will be different for a given loading of ceramic on ceramic, a ceramic on steel or steel on steel. This was first recognized by Carter and Zaretsky (1960) in their work with a crystallized glass ceramic. For the case of a ceramic on steel, it is assumed that the ceramic material will have infinite life and that the steel races will be the element to fail from rollingelement fatigue. Since life is inversely proportional to stress to a power, the life of a hybrid bearing (ceramic rolling element on steel races) will generally be lower than that for a full compliment steel bearing. This can be illustrated as follows:

From Hertz theory for two spheres of radi $R_{a}$ and $R_{b}$ in contact (Jones, 1946) the maximum compressive stress is

$$
S_{\max }=\frac{3 P_{0}}{2 \pi r^{2}}
$$

where

$p$ normal load

r contact radius

For two spheres in contact the Hertzian contact area: a circle with radius $r$.

$$
r=\left[\frac{3 P_{0}\left(N_{a}+N_{b}\right)}{8\left(\frac{2}{R_{a}}+\frac{2}{R_{b}}\right)}\right]^{i / 3}
$$

For two spheres of equal radi;

$$
R_{a}=R_{b}=R
$$

Then

$$
r=\left[\frac{3 P_{0} R\left(N_{a}+N_{b}\right)}{32}\right]^{1 / 3}
$$

where

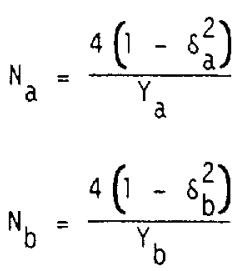

and

$y$ modulus of elasticity

$\delta$ Poisson's ratio

Then

$$
\begin{aligned}
r & =K_{1}\left[\frac{1-\delta_{a}^{2}}{Y_{a}}+\frac{1-\delta_{b}^{2}}{Y_{b}}\right]^{1 / 3} \\
& =K_{1}\left[\frac{Y_{b}\left(1-\delta_{a}^{2}\right)+Y_{a}\left(1-\delta_{b}^{2}\right)}{Y_{a} Y_{b}}\right]^{1 / 3}
\end{aligned}
$$

where

$K_{1}=\left[\frac{3 P_{0} R}{8}\right]^{1 / 3}$ 
Substituting Eq. (6) into Eq. (3),

$$
S_{\max }=K_{2}\left[\frac{Y_{a} Y_{b}}{Y_{b}\left(1-\delta_{a}^{2}\right)+Y_{a}\left(1-\delta_{b}^{2}\right)}\right]^{2 / 3}
$$

where

$$
K_{2}=\frac{3}{8 \pi}\left[\frac{p_{0}}{g R^{2}}\right]^{1 / 3}
$$

For steel on steel

$$
S_{\max }=K_{2}\left[\frac{Y_{s}}{2\left(1-\delta_{s}^{2}\right)}\right]^{2 / 3}
$$

The relative life, $\vec{L}_{H_{R}}$, for the same load on a steel bearing and a hybrid bearing would be as follows:

$$
\frac{\bar{L}_{H_{R}}}{L_{S}}=\left(\frac{S_{\max }}{S_{\max _{H}}}\right)^{n}
$$

Letting $\bar{L}_{S}=1$ and $n=9$ and substituting Eq. (8) in Eq. (g),

$$
\bar{L}_{H_{R}}=\left[\frac{1}{2}+\frac{Y_{s}\left(1-\delta_{c}^{2}\right)}{2 Y_{C}\left(1-\delta_{s}^{2}\right)}\right]^{6}
$$

Equation (10) is a stress correction factor based upon a ninth power of the ratio of the Hertz stress in the contact of a ceramic or cermet ball or roller and a steel race to that of a steel rolling element on a steel race for identical contact load and geometry. The factor $\bar{L}_{H_{R}}$ for various rolling-element materials is listed in Table III. $\bar{L}_{H_{R}}$ can be multiplied by the calculated life of a full-complement or all steel rolling element bearing to obtain the life of a hybrid bearling using the applicable materlal in Table III as the rolling elements. This simplified correction neglects the effect of stressed volume on fatigue life. However, this effect is found to be small relative to the stress effect. In fact, it is easily shown that the small stressed volume effect is nearly offset by the additional effect of the depth of the maximum shear stress (Parker and Zaretsky, 1975). From the Lundberg-Palmgren analys is (Lundberg and Palmgren. 1947; Lundberg and Palmgren, 1949; and Lundberg and Palmgren, 1952),

$$
\frac{\bar{L}_{H}}{L_{S}}=\left(\frac{Z_{H}}{Z_{S}}\right)^{2.1}\left(\frac{V_{S}}{V_{H}}\right)^{0.9}\left(\frac{\tau_{S}}{\tau_{H}}\right)^{9.3}
$$

where

L contact life

$z$ depth to maximum shear stress

$V$ stressed volume

$\tau$ maximum shear stress

From the Hertzian equations for 1 ine contact (Jones, 1946) where the ellipticity ratio is 0 and from Eq. (10) letting

$$
E=\left[\frac{1}{2}+\frac{Y_{s}\left(1-\delta_{c}^{2}\right)}{2 Y_{C}\left(1-\delta_{s}^{2}\right)}\right]
$$

then

$$
\begin{aligned}
& \frac{Z_{H}}{Z_{S}}=E^{2 / 3} \\
& \frac{V_{S}}{V_{H}}=E^{-2 / 3} \\
& \frac{\tau_{S}}{\tau_{H}}=E^{2 / 3}
\end{aligned}
$$

Substituting Eqs. (12) to (15) into Eq. (11) and letting $\bar{L}_{S}=1$, then for ine contact,

$$
\bar{L}_{H_{R}}=\left[\frac{1}{2}+\frac{{ }_{S}\left(1-\delta_{C}^{2}\right)}{2 Y_{C}\left(1-\delta_{S}^{2}\right)}\right]^{6.97}
$$

For point contact where the ellipticity ratio is 1 (Jones, 1945).

$$
\begin{aligned}
& \frac{z_{H}}{z_{S}}=E^{1 / 3} \\
& \frac{V_{S}}{V_{H}}=E^{-2 / 3} \\
& \frac{\tau_{S}}{\tau_{H}}=E^{2 / 3}
\end{aligned}
$$

Equations (18) and (19) are identical to Eqs. (14) and (15), respectively. Substituting Eqs. (12) and (17) to (19) into Eq. (11) and letting $\bar{L}_{5}=1$, for point contact,

$$
\bar{L}_{H_{R}}=\left[\frac{1}{2}+\frac{{ }_{s}\left(1-\delta_{c}^{2}\right)}{{ }^{Y_{C}}\left(1-\delta_{s}^{2}\right)}\right]^{6.3}
$$

Using Eq. (10) and the elastic properties listed in Table II, the relative lives and dynamic capacities of a hybrid bearing comprising rolling elements of the matertals listed are given in Table III. 
Hybrid 57-mm bore cylindrical rolier bearings each containing 20 each crowned, $7.1-m m$ diameter silicon nitrice rollers were endurance tested (Baumgartner and Cowley, :975). The bearing rings were consumableelectroce vacuum-melted (CVM) AISI M-50. Test conditions were at an outer-race temperature 356 to $380 \mathrm{~K}$ (200 to $225^{\circ} \mathrm{F}$ ), a radial load of $22464 \mathrm{~N}(5050 \mathrm{ib})$ croducirg a maximum Hertz stress of $2.82 \times 10^{9} \mathrm{~N} / \mathrm{m}^{2}$ (408000 psi), a shaft speed of $5400 \mathrm{rpm}$ and a triester lubricant (MIL-L-236998). The catalog ife of an equivalent steel bearing was calculated to be $21.6 \mathrm{hr}$ without any 1 ife adjustment factors (Baumgartner and Cowley, 1975). Using the ASME design guide (Bamberger et al., 971), the following life adjustment factors are obtained: (a) material factor, 2: (b) processing factor, 3 ; and (c) lubricant factor, i.5. Combining these factors $(2 \times 3 \times 1.5)$, a life adjustment factor of 9 can be used for a CVM AISI M-50 steel bearing under these operating conditions. The adjusted predicted life of an all steel bearing would equal $(9 \times 21.6) 194.4 \mathrm{hr}$ at a 90-percent probability of survival. From Eq. (10) and Table III for silicon nitride, the life adjustment factor for the hybrid bearing is 0.29 . Hence, the predicted life of the hybrid roller bearing would be $(0.29 \times 194.4)$ $56.4 \mathrm{hr}$. Using Eq. (16) for line contact, and Eq. (20) for point contact, the predicted lives would be $(0.24 \times 194.4) 46.7$ and $(0.28 \times 194.4) 53.5 \mathrm{hr}$. respectively. From Fig. 3 , the $11 \mathrm{fe}$ of the hybrid bearing was approximately $48 \mathrm{hr}$. There were an unusual number of silicon nitride roller failures and roller damage in many of the failed bearings including roller fracture. These results would indicate that the high Hertzian stress at which the bearing was run exceeded the capability of the silicon nitride material.

\section{EFFECT OF TEMPERATURE}

Lubricated rolling-element tests were conducted in the NASA five-ball fatigue tester with the crystallized glass ceramic, hot-pressed alumina, cold-pressed alumina, self-bonded silicon carbide and nickle-bonded titanium carbide at temperatures to $1366 \mathrm{~K}\left(2000^{\circ} \mathrm{F}\right.$ ) (Carter and Zaretsky, 1960; Zaretsky and Anderson, 1961; Parker et al., 1965; Parker et a1.. 1964a: and Parker et al., 1964b). The crystallized ceramic was only tested to $644 \mathrm{~K}\left(700^{\circ} \mathrm{F}\right)$ (Carter and Zaretsky. 1950 and Zaretsky and Anderson, 1961). There are no fatigue results reported for silicon nitride beyond nominal temperature under lubricated conditions. Shorter lives were exhibited at $644 \mathrm{~K}\left(700^{\circ} \mathrm{F}\right)$ for these materials. This decrease in life may be accounted for by a change in lubricant viscosity with temperature. As the viscosity of the lubricant decreases any elastohydrodynamic film separating the rolling elements will decrease. The life of a rolling element in addition to its own material properties is a function of the elastohydrodynamic film thickness (Bamberger et al., 1971). Hence, the life of these naterials may be affected in a similar manner as steel. Three materials were run in a modifled five-ball fatigue tester to temperatures of $1366^{\mathrm{K}}\left(2000^{\circ} \mathrm{F}\right)$ with molybdenum disulfide-argon mist lubrication (Parker et a 1., 1965; Parker et a1., 1964a; Parker et al., 1964b). The results of these tests indicated that the hotpressed alumina was capable of operating to temperatures of $1366 \mathrm{~K}\left(2000^{\circ} \mathrm{F}\right)$. However, tests with the cold-pressed alumina and silicon carbide at $1366 \mathrm{~K}$ $\left(2000^{\circ} \mathrm{F}\right)$ and maximum Hertz stresses of $1.66 \times 10^{9} \mathrm{~N} / \mathrm{m}^{2}$ (270 000 psi) resulted in general track deterforation unlike the failure pits or spalls observed at 300 and $644 \mathrm{~K}\left(80\right.$ and $\left.700^{\circ} \mathrm{F}\right)$. Titanium carblde cermet at temperatures beyond $855 \mathrm{~K}\left(1100^{\circ} \mathrm{F}\right)$ and a maximum Hertz stress of $1.91 \times 10^{9} \mathrm{~N} / \mathrm{m}^{2}$ (3i0 000 psi), exhibited excess cumulative plastic deformation, which indicated that this material is limited to less-severe conditions oi temperature and stress.

Surface-failure data with hot-pressed alumina tested at $1366 \mathrm{~K}\left(2000^{\circ} \mathrm{F}\right)$ and a maximum Hertz stress of $3.39 \times 10^{9} \mathrm{~N} / \mathrm{m}^{2}$ (550 000 psi) are given in $\mathrm{Fig}$. $4(\mathrm{a})$ together with the experimental lives at 300 and $544 \mathrm{~K}$ $\left(80\right.$ and $700^{\circ} \mathrm{F}$ ) (at the same stress) out with a mineral-oil lubricant. Figure $4(b)$ is a plot of the 10 - and 50-percent lives of the material as a function of temperature. While the mode of lubrication at the lower temperatures and $1366 \mathrm{~K}\left(2000^{\circ} \mathrm{F}\right)$ is different. the figure provides not only a relative indication of the life performance of the hot-pressed alumina to $1366 \mathrm{~K}\left(2000^{\circ} \mathrm{F}\right)$ but also of the other refractory materials with temperature where $\bar{L} \sim 1 / T$. From Fig. $4(b), m=1.8$; where temperature is in Kelvin or Rankine.

\section{EFFECT OF SPEED ON LIFE}

At high aircraft turbine engine speeds, the effect of centrifugal loading of the rolling elements of a bearing against the bearing outer race becomes extremely important. Theoretical ife calculations for a $150-\mathrm{mm}$ bore angular-contact ball bearing operating at 3 million DN (20000 rpm) (DN is bearing speed in $\mathrm{rpm} x$ bearing bore in $\mathrm{mm}$ ) predict that this bearing has approximately 20 percent AFEMA-calculated life

(Scibbe and Zaretsky, 1971). The decrease in predicted life is due to the increased stress in the outer race caused by centrifugal effects. The expected final result is extremely short bearing life at speeds much above 2 million DN both in actual running time (hr) and in total bearing inner-race revolutions. In order to reduce the centrifugal force effects, concepts such as hollow and hollowed rolling elements and lightweight ceramic rolling elements have been considered as a substitute for the conventional rolling elements contained within the bearing. Silicon nitride has been one such material.

Computer analysis of the dynamic performance characteristics of ball bearings was used to evaluate the effect of the low mass silicon nitride balls on $120-\mathrm{mm}$ bore angular-contact ball bearing fatigue life (Parker and Zaretsky, 1975). The and ysis was performed with both steel and silicon nitride balis with steel inner and outer races. Figure 5 is a summary of the results for three thrust loads. In general, this analysis indicates that the use of silicon nitride balls to replace steel balls in high-speed bearings will not yield an improvement in fatigue iffe over the speed range of anticipated advanced air-breathing engine main-shaft ball bearings up to 3 million DN. However, at some conditions of very high speeds and light loads. modest life improvements are indicated, but only if modifications are made in bearing internal geometry (inner-race curvature, for example) (Parker and Zaretsky, 1975).

Bearing life calculations were made with reduced curvature at the inner race $(0.52$ as opposed to 0.54$)$ (Parker and Zaretsky, 1975). With the exception of very low loads and very high speeds, the life improvements over the steel ball cases are small. For the case of $3 \mathrm{million} D \mathrm{~N}$ and $13300 \mathrm{~N}(3000 \mathrm{lb})$ thrust load, the life improvement is less than 14 percent (Parker and Zaretsky, 1975).

\section{HEAT GENERATION AND TEMPERATURE}

In a discussion to Reddecliff and Valori (1976), Coe and Zaretsky reported results obtained with a 115 
series, $75-\mathrm{mm}$ bore ball bearing with steel balls aperated at a $4400 \mathrm{~N}(1000$ lb) thrust load up to $2.0 \times 10^{\circ}$ DN at NASA. The steel balls were then replaced with silicon nitride balis and the test repeated. Figure 6(a) is a comparison of the outer-race temperature for both bearings over a range of shaft speed. The outer-race temperature was almost the same for ooth silicon nitride and the steel balis. However. Fig. $\sigma(b)$ is a comparison of the bearing torque over the same speed range. It is apparent that the bearing with silicon nitride balls showed significantly higher toraue than the same bearing with steel balls. The torque was measured directly by a force transducer connected to the periphery of the bearing housing. The higher torque with the silicon nitride balls can be explained in part by the fact that the traction coefficient of a lubricant is a function of the viscosity of the oil under the contact pressure (Loewenthal and Zaretsky, 1985). Since for a given load, the contact stress with the silicon nitride balls are higher than with the steel balls, the viscosity of the oil in the contact zone is higher. Because of the higher viscosity, the traction in the contact zone of the bearing must be accordingly higher.

It was reported by Reddecliff and Valori (1976) that a 33-percent reduction in axial preload to prevent skidding in a $35-\mathrm{mm}$ bore angular-contact ball bearing was achieved by substituting sillcon nitride balls for steel balls. This would tend to substantlate that a higher traction force in the bearing may exist with a given load as a result of the higher viscosity with higher contact stress. Higher traction forces should result in higher heat generation with the sllicon nitride bails. However, data reported in Reddecliff and Valorl (1976) (Fig. 7) show that with the silicon nitride balls in the $35-m m$ bearing, the heat generation was lower ( $F \mathrm{gg} .7(\mathrm{a})$ ) even though the outer-race temperatures were almost identical (Fig. $7(b)$ ).

There are possible explanations for the difference in these results. There could, of course, be an effect due to bearing size. For example, the computer program used in Parker and Zaretsky (1975) indicates that about 60 percent of the calculated heat generation was due to ball spin for a $35-\mathrm{mm}$ bore bearing, whereas it was about 50 percent for a $120-\mathrm{mm}$ bore bearing. Further, the oil used for the 75-mm bearing tests was superreflned naphthenic mineral oil with undoubtedly different viscosity characteristics from those of the oil used in Reddecliff and Valori (1976). Also, the 75-mm bearings were lubricated directiy by oll jet, not through the race as those of Reddecliff and valori (1976). Finally, it should be noted that the diameter of the silicon nitride balls used in the 75 -mm bearing differed less than $0.5 \mu m(20 \mu i n$.$) from the steel$ balls, at room temperature. Therefore, at operating temperature, the bearings were slightiy different, due to the lower coefficient of expansion of the silicon nitride

Data were reported for AISI M-50 $35-\mathrm{mm}$ roller bearings (Baumgartner et al., 1976) comparing the heat generated in a hybrid roller bearing with the same size bearing having steel rollers and approximately the same radial load. It was concluded in Baumgartner et al. (1976) that the heat generation for the hybrid bearing was comparable to that of the bearing with the steel rollers. It can be concluded that the bearing power loss or heat generation is more a function of the individual bearing design and operation than whether steel or ceramic rolling elements are used within the bearing.

\section{UNLUBRICATED BEARINGS}

It has been proposed that unlubricated ceramic bearings offer an approach toward meeting operating requirements in excess of $578 \mathrm{~K}\left(600^{\circ} \mathrm{F}\right)$ where both conventional and nonconventional liquid iubricants are not capable of sustaining these higher temperatures nor of providing an elastonydrodynamic film. Tests of full complement 17-mm bore silicon nitride cylindricai roiler bearings were performed at $644 \mathrm{~K}\left(700^{\circ} \mathrm{F}\right.$ ) (Bailey, 1984). The test vehicle used to evaluate these bearings was a modified 3402 Turbojet engine. The first test resulted in a catastrophic bearing failure after $11-1 / 2$ min of operation due to fracture of the ceramic. The second test ran for a total time of $2 \mathrm{hr}$ and $3 \mathrm{~min}$ of which $54 \mathrm{~min}$ were run unlubricated. In the uniubricated condition, 30 min were run at shaft speeds between 39000 and $39600 \mathrm{rpm}$ or in excess of $660000 \mathrm{DN}$. However, residual lubricant may have been present to sustain the bearing for the $54 \mathrm{~min}$. A totally unlubricated endurance test was run with a René 41 goldplated cage. A catastrophic failure was encountered after $30 \mathrm{~min}$ of operation due to fracture of the ceramic.

Solid film lubricants applied in a manner similar to that reported in Parker et al. (1965) may be capable of sustaining full complement ceramic roller bearings at these nigher temperatures for longer periods of time. However, extensive work is required to both prove and develop this concept for practical turbine engine applications.

\section{BEARING MOUNTING}

The use of full complement ceramic rolling-element bearings presents unique mounting problems. Referring to Table II, the thermal expansion of the refractory materials are less than that of steel. As a result. where a ceramic bearing is mounted on a steel shaft. large hoop stresses can be induced in the bearing inner ring which can result in fracture of the ring. Hosang (1987) proposes the use of a corrugated iner interposed between the journal and the bore of the inner ring. The corrugations run parallel to the bearing and journal axis. This is illustrated in Fig. 8 . In principle, the liners diametral thermal expansion is less than that of the shaft journal. The difference is accommodated by stretching of the liner in the circumferential direction. According to Hosang (1987), this action also reduces the envelope outer diameter of the corrugations from that dictated by thermal expansion. The radial stiffness of the liner should also be as high as possible so as not to affect the stiffness of the bearing. An alternate design proposed by Hosang (1987) is the use of the corrugated liner and conical retainers shown in $\mathrm{Fig}, 8(\mathrm{a})$.

Bafley (1983) reports the use of a collar for the inner ring and a spacer for the outer ring tc accommodate differences in thermal expansion ( $F \mid g .9$ ).

Baumgartner et al. (1973), use a clamping collar against the inner ring. The axial clamping force is maintalned by the clamping collar with an angled face to match the face angle of the inner ring. As the shaft expands axially, the radial expansion forces the collar against the inner ring face, holding it in position.

The use of full complement ceramic bearings require special mounting design conslderations not currently used in turbomachinery. Consequently, these 


\section{CFIGFYAL PAGE IS \\ CF POOK QUALITY}

bearings cannot be substituted for steel bearings without extensive design modifications of the rotating shaft and housing.

MANUFACTIRING AND PROCESSING

It has long been recognized that voids or surface defects in ceramic or cermet rolling elements can be the source of a subsurface or surface induced soall Carter and Zaretsky, 1960: Zaretsky and Anderson, :361: Parker et al., 1965; Parker and Zaretsky, i974; zarker et al., 1964a: and Parker et al., 1964b). As critical flaw sizes are reduced, it is probable that the values of dynamic capacity summarized in Table I and life can be increased. Thus, processing and manufacturing methods can be critical to long iife functioning.

In recent years, a relatively large effort has been devoted to the processing and manufacture of silicon nitride bearings (Bhustian and Sibley, 1982; Dalal et al., 1977; Baumgartner and Cowley, 1976; and Baumgartner and wheidon, 1973). The most commonly used processing method is hot processing. In hot processing the powder is sized, blended with hot-processing aids and pressed in graphite dies using temperatures in the 1973 to $2173 \mathrm{~K}\left(3091\right.$ to $3451{ }^{\circ} \mathrm{F}$ ) range and pressures above $14 \mathrm{MPa}$. The most common sintering aid is the addition of 1 to 2 percent MgO (Bhushan and Sibley. 1982).

Other processes include blending of silicon nitride powder with a binder and then cold pressing to near-net shape preforms. The cold-pressed parts are subsequentiy sintered at high temperature without application of the high pressures present in hot processing (Bhushan and Sibley, 1982). Another processing method is hot isostatic pressing or partial sintering and then hot isostatic pressing (Bhushan and sibley, 1982). Cold processing silicon and reaction sintering in hot, high-pressure nitrogen called reaction bonding is still another method.

Silicon nitride is hot pressed into billets in the form of plates and then diamond machined. The material can be hot pressed directiy into blanks of the required shape for bearing rings, balis, and rollers using suitable multiple cavity graphite molds (Bhushan and Sibley, 1982).

The rolling-element fatigue life of silicon nitride was found to be strongly influenced by finishing procedures (Bhushan and Sibley, 1982; Baumgartner and Cowley, 1976; and Baumgartner and Wheidon, 1973). As with steels, improved rolling-element fatigue life was obtained with better surface finishes (Baumgartner and Cowley, 1976 and Baumgartner and wheidon, 1973). The machining of silicon nitride for bearing application begins with ultrasonic machining, followed by diamond grinding, and then by lapping and polishing (Bhushan and sibley, 1982). Surface preparation should insure that coarse grit grinding damage is removed during final finish (Baumgartner and wheidon, 1973).

It was recommended by Baumgartner and Cowley (1976) that, for producing silicon nitride rollers with a straight roller geometry, diamond grinding and honing be used. The use of a formed silicon carbide whee? after initial diamond wheel grinding was recommended for shaping crowned rolier geometries (Baumgartner and Cowley, 1976).

SUMMARY

For three decades research has been performed into the use of nonmetallic and refractory materials as rolling-element materials for use in gas turbine engines. Materials and bearing design methods have continuously improved over the years. Materials such as alumina, silicon carbide, titanium carbide, si: con nitride, and a crystallized glass ceramic have been investigated by NASA in the past. Rolling-element endurance tests and analysis of full-complement bearings were performed. The following resuits were obtained:

1. Silicon nitride material oroduces the longes: life of the materials studied. However. She dynamic capacity of a full complement z:i con nitrice bearing will be only 5 to 12 percent that of an ail steel cearing of similar geometry.

2. The use of bearings naving ceramic rolling elements and steel races can result in : ves less than full complement steel bearings where the eiastic modulus of the ceramic is greater than steel as in the case of most ceramics.

3. Bearing power loss or heat generation is more a function of the individual bearing design and operation than whether steel or ceramic rolling elements are used within the bearing.

4. The lives of ceramic rolling elements are an inverse function of temperature. It is suggested based upon endurance tests with alumina to $1366 \mathrm{~K}$ (2000 of) that 1 ife is inversely proportional to temperature to the 1.8 power.

5. Unlubricated tests of a full-complement silicon nitride bearing at $644 \mathrm{~K}\left(700^{\circ} \mathrm{F}\right)$ resulted in catastrophic failure after $30 \mathrm{~min}$ suggesting the need for lubrication at elevated temperatures.

6. Special design and mounting requirements are needed to accommodate a full-complement ceramic bearing into turbomachinery applications. Optimum designs nave yet to be developed.

\section{ACKNOWLEDGMENTS}

The author wishes to acknowledge the technical contributions of Richard J. Parker and Salvatore $J$. Grisaffe who with his other colleagues at the NASA Lewis Research Center collaborated with him in conducting the NASA nonmetallic bearing research over tne years which is reported herein. Also, the author wishes to thank Mr. Grisaffe for his technical recommendations and comments which have been incorporated throughout this paper.

\section{REFERENCES}

Appeldoorn, J.K. and Royle, R.C., 1965, "Lubricant Fatigue Testing with Ceramic Bails, "Lubrication Engineering, Voi. 21, No. 2, pp. 45-51.

Bailey, T.E., 1984, "Ceramic Roller Bearing Development Program," NAPC-PE-i06-C. (Avail. NTIS, AD-E086757L).

Bamberger, E.N., 1971, Life Adjustment Factors for Ball and Roller Bearings - An Engineering Design Guide, ASME, New York.

Baughman, R.A. and Bamberger, E.N., 1963, "Uniubricated High Temperature Bearing Studies," Journal of Basic Engineering, Vol. 85, No. 2, pp. 265-272.

Baumgartner, H.R. and Cowley, P.E., 1975, "Silicon Nitride in Rolling Contact Bearings, "Norton Co., Worcester, MA. (Avail. NTIS, AD-AO15990)

Baumgartner, H.R. and Cowley, P.E., 1976, "Finishing Techniques for Silicon Nitride Bearings," AMMRC-CTR-76-5.. (Avai1. NTIS, AD-A025350). 
Eaumgartner, H.R. and Whieldon, W.M., 1973, "Rolling Contact Fatigue Performance of Hot-Pressed Silicon Nitide versus Surface Preparation Techniques," Surface and Interfaces of Glass and Ceramics, V.D. Frechette, W.C. LaCourse, and V.L. Burdick, eds., Plenum Press, New rork, pp. 179-193.

Eaumgartrer, H.R., 1973, "Evaluation of Roller Bearings Containing Hot Pressed Silicon Nitride Rolling E'ements," Ceramics for High Performance Applications, A.J. Surke, A.E. Gorum, and R.N. Katz, eds., Brook Hili Publishing Co., Chestnut Hill, MA, pp. 713-727.

Baumgartiner, H.R., Calvert, G.S., and Cowley, P.E., 1976. "Ceramic Materials in Rolling Contact Bearings," Norton Co., Worcester, MA. (Avail. NTIS, AD-A031560).

Baumgartner, H.R., Lundberg, D.V., and Whiedon, W.J., 1973. "Silicon Nitride in Rolling Contact Bearings," Norton Co., Worcester, MA. (Avail. NTIS, AD-771393).

Bhushan, 3. and Sibley, L.B., 1982, "Silicon Nitride Rolling Eearings for Extreme Operating Conditions, ASLE Transactions, Vol. 25. No. 4, pp. 417-428.

Carter, T.L. and Zaretsky, E.V., 1950, "Rolling Contact Fatigue Life of a Crystallized Glass Ceramic, "NASA TN $0-259$.

Dalal, H.M., Rosenlieb, J.W., and Sibley, L.B., 1977, "Develooment of Basic Processing Technology for Bearing Quality Silicon Nitride Balls," SKF-AL77T057, SKF industries, king of Prussia, PA. (Avall. NTIS, $A 0-A 053330$ )

Dee, C.W., 1970, "Silicon Nitride-Tribological Aopli cations of a Ceramic Material," Tribology, vol. 3, No. 2, pp. 89-92.

Harris, T.A., 1968, "On the Effectiveness of Hollow Bal is in High-speed Thrust Bearings," ASLE

Transactions, Vol. 11, No. 4, pp. 290-294.

Hosang, G.W., 1987, "Results and Design Techniques from the Appication of Ceramic Ball Bearings to the MERADCOH IOK'N Turbine," AIAA Paper 87-1844.

Jones, A.8., 1946. Analys is of Stresses and Deflections, Vols. I and II, General Motors, New Departure Division, Bristol, CT.

Loewenthal, S.H. and Zaretsky, E.V., 1985, "Traction Orives," Mechanical Design and Systems Handbook, 2nd Edition, 4.A. Rothbart, ed., McGraw Hill. New York. 1985, pp. 34.1-34.56

Lundberg, G. and Palmgren, A., 1947, "Dynamic Capacity of Rolling Bearings, "Acta Poiytechnica, Mechanical Engineering Series, vol. 1, No. 3, pp. i-50.

Lundberg, G. and Palmgren. A., 1949, "Dynamic Capacity of Roiling Bearings, Journal of Applied Mechanics. vol. 16, No. 2, pp. 165-172.

Lundberg. G. and Palmgren, A., 1952, "Dynamic Capacity of Rolier Bearings," Acta Polytechnica, Mechanical Engineering Series, Vol. 2, No. 4.

Miner, J.R., Grace, W.A., and Valori, R., 1981, "A Demonstration of High-Speed Gas Turbine Bearings Using Silicon Nitride Rolling Elements, "Lubrication

Engineering, Vol. 37, No. 8, pp. 462-464, 473-478.
Parker, R.J. and Zaretsky, E.V., 1975, "Fatique Life of High-Speed Ball Bearings with Silicon Nitride Balls." Journal of Lubrication Technology, Vol. 97, No. 3. pp. $350-357$.

Parker, R.J. and Zaretsky, E.V., 1972, "Reevaluation of the Stress-Life Reiation in Roling-Element Eearings, NASA TN D-6745.

Parker, R.J. and Zaretsky. E.V., 1974, "Rolling-Elemer: Fatique Life of Silicon Nitride Balls," NASA TN J-7794.

Parker, R.J. and Zaretsky, E.V., 1972, "Rolling-Elertert: Fatigue Lives of Through-Hardened Eearing Materials," Journal of Lubrication Technology, Vol. 94, No. ?, pp. 165-173.

Parker, R.J., Grisaffe, S.J., and Zaretsky, E.V., 1965. "Rolling-Contact Studies With Four Refractory Materials to $2000^{\circ} \mathrm{F}$." ASLE Transactions, Vol. 8, No. 3, pp. $208-216$.

Parker, R.J., Grisaffe, S.J., and Zaretsky, E.V., 1964, "Surface Failure of Alumina Balls Due to Repeated Stresses Applied in Rolling Contact at Temperatures of $2000^{\circ} \mathrm{F}$," NASA TN D-2274.

Parker, R.J., Grisaffe, S.J., and Zaretsky, E.V., 1964, "Surface Failure of Titanium Carbide Cermet and Silicon Carbide Balls in Rolling Contact at Temperatures to $2000^{\circ} \mathrm{F}$," NASA TN $0-2459$.

Reddecliff, J.M. and Valori, R., 1976, "The Performance of a High-Speed Ball Thrust Bearing Using Silicon Nitride Balls," Journal of Lubrication iechnology, Vol. 98, No. 4, pp. 553-563.

Scibbe, H.W. and Zaretsky, E.V., 1971, "Advanzed Design Concepts for High Speed Bearings," ASME Paper $71-0 E-50$. (NASA TM $X-52958$ ).

Scott, D. and Blackwe11, J., 1973, "Hot-Pressed Silicon Nitride as a Rolling Bearing Material--A Preliminary Assessment," Wear, Vol. 24, No. 1, pp. 61-67.

Scott, D., Bälckwell, J., and McCullagh, P.J., 1971, "Silicon Nitride as a Rolling Bearing Materia" --A Preliminary Assessment," Wear, Vol. 17, No. 1. pp. 73-82.

Sibley, L.B., Mace, A.E., Griesir, D.R., and Allen, C.M., 1960, "Characterlstics Governing the Friction and Wear Behavior of Refractory Materials for High-Temperature Seals and Bearings," WADD-TR-60-54.

Taylor, K.M., Sibley, L.B., and Lawrence, J.C., 1963. "Development of a Ceramic Rolling Contact Bearing for High Temperature Use," Wear, Vol. 6, No. 3 , pp. $226-240$.

Zaretsky, E.V. and Anderson, w.J., 1961, "RollingContact Fatigue Studies with Four Tool Steels and a Crystallized Glass Ceramic, "Journal of Basic Engineering, Vol. 83, No. 4, pp. 603-612. 


\section{OT:THA FAGE IS \\ $\therefore \quad C$ CUALTTY}

TABLE 1. - STRESS-LIFE EXPONENT ANO RELATIVE OYNAMIC CAPACITY OF MATERIALS FOR ROLIING-ELEMENT BEARING APPLICATION

\begin{tabular}{|c|c|c|}
\hline Material & $\begin{array}{c}\text { Stress-ife exponent, } \\
n\end{array}$ & $\begin{array}{l}\text { Dynamic capacity } \\
\text { relative to steel }\end{array}$ \\
\hline Crystalizized glass ceramica & $\begin{array}{l}10.5 \text { to } 13.8 \\
\text { (Average value, } 11.6 \text { ) }\end{array}$ & 0.07 \\
\hline Hot-pressed aluminab & $\begin{array}{l}9.4 \text { to } 10.8 \\
\text { (Average value, } 10.6 \text { ) }\end{array}$ & 0.07 \\
\hline Cold-pressed aluminab & $\begin{array}{c}5.0 \text { to } 8.1 \\
\text { (Average value, 7) }\end{array}$ & 0.01 \\
\hline $\begin{array}{l}\text { Self-bonded silicon } \\
\text { carbideb }\end{array}$ & $\begin{array}{l}6.9 \text { to } 8.6 \\
\text { (Average value, } 7.8 \text { ) }\end{array}$ & 0.01 \\
\hline $\begin{array}{l}\text { Nickle-bonded titanitum } \\
\text { carbideb }\end{array}$ & $\begin{array}{l}9.7 \text { to } 10.5 \\
\text { (Average value, 10.2) }\end{array}$ & 0.03 \\
\hline Silicon nitride $\bar{c}$ & $\begin{array}{l}16 \text { to } 16.2 \\
\text { (Average value, 16.1) }\end{array}$ & 0.05 to 0.12 \\
\hline Bearing steel & $\begin{array}{c}9 \text { to } 10 \\
\text { (Accepted value, 9) }\end{array}$ & 1.00 \\
\hline
\end{tabular}

aCarter, et al. (1960); 2aretsky, et al. (1961).

bparker, et al. (1965).

CBaumgartner, et al. (1973); Parker, et al. (1975); Parker, et al. (1974).

TABLE II. - TYPICAL PHYSICAL AND THERMAL PROPERTIES OF MATERIALS FOR ROLLING-ELEMENT BEARING APPLICATION

[Carter, et al. (1960); Zaretsky, et al. (1961); Parker, et al. (1965); Baumgartner, et al. (1973) Parker, et al. (1975); Parker, et al. (1974); Parker, et al. (1964); Bhushan, et al. (1982).]

\begin{tabular}{|c|c|c|c|c|c|c|c|c|c|}
\hline \multirow[t]{2}{*}{ Material } & \multirow{2}{*}{$\begin{array}{l}\text { Rockwell C } \\
\text { hardness at } \\
294 \mathrm{~K} \\
\left(70^{\circ} \mathrm{F}\right)\end{array}$} & \multirow{2}{*}{$\begin{array}{c}\text { Est I mated } \\
\text { maximum } \\
\text { usable } \\
\text { bearing } \\
\text { temperature, } \\
\mathrm{K} \\
\left({ }^{\circ} \mathrm{F}\right)\end{array}$} & \multirow[t]{2}{*}{$\begin{array}{l}\text { Denslty. } \\
\text { gm/cc }\end{array}$} & \multirow{2}{*}{$\begin{array}{l}\text { Elastic } \\
\text { modulus } \\
\text { at } 294 \mathrm{~K} \\
\left(70^{\circ} \mathrm{F}\right) \\
\left(10^{6} \mathrm{GPa}\right. \\
\mathrm{Ps} 1)\end{array}$} & \multirow[t]{2}{*}{$\begin{array}{l}\text { Poisson's } \\
\text { ratio, } \\
\text { \& }\end{array}$} & \multicolumn{2}{|c|}{$\begin{array}{l}\text { Therma l conductivity, } \\
\text { w/mk (BTu ft/hr-ft }{ }^{2}-F \text { ) } \\
\text { at }\end{array}$} & \multirow{2}{*}{$\begin{array}{l}\text { Coefficient of } \\
\text { thermal } \\
\text { expansion, } \\
10^{-6} \mathrm{~K} \\
\left(10^{-6} /{ }^{\circ} \mathrm{F}\right) \\
273 \text { to } 1073 \mathrm{~K} \\
\left(32 \text { to } 1471^{\circ} \mathrm{F}\right)\end{array}$} & \multirow{2}{*}{$\begin{array}{l}\text { Weibulib } \\
\text { slope or } \\
\text { modulus. } \\
\text { e }\end{array}$} \\
\hline & & & & & & $\begin{array}{l}294 \mathrm{~K} \\
\left(70^{\circ} \mathrm{F}\right)\end{array}$ & $\begin{array}{l}1073 \mathrm{~K} \\
\left(1471^{\circ} \mathrm{F}\right)\end{array}$ & & \\
\hline $\begin{array}{l}\text { Crystallized } \\
\text { glass ceramic }\end{array}$ & .53 & $\begin{array}{l}7644 \\
(700)\end{array}$ & 2.5 & $\begin{array}{c}87 \\
(12.5)\end{array}$ & 0.25 & $\begin{array}{c}1.6 \\
(0.9)\end{array}$ & $\begin{array}{l}2.0 \\
(1.2) \text { at } \\
873^{K} \\
\left(1112^{\circ} \mathrm{F}\right)\end{array}$ & $\begin{array}{c}0.4 \\
(0.2)\end{array}$ & 3.3 \\
\hline Alumina & 85 & $\begin{array}{l}\sim 1367 \\
(2000)\end{array}$ & 3.9 & $\begin{array}{l}350 \\
(51)\end{array}$ & 0.25 & $\begin{array}{l}7.2 \\
(4.2)\end{array}$ & $\begin{array}{l}1.7 \\
(1.0)\end{array}$ & $\begin{array}{c}8.5 \\
(4.7)\end{array}$ & 2.7 \\
\hline sllicon carbide & 90 & $\begin{array}{l}(1367 \\
(2000)\end{array}$ & 3.2 & $\begin{array}{l}410 \\
(59)\end{array}$ & 0.25 & $\begin{array}{c}35 \\
(20)\end{array}$ & $\begin{array}{l}12 \\
(6.9)\end{array}$ & $\begin{array}{l}5.0 \\
(2.8)\end{array}$ & 2.1 \\
\hline $\begin{array}{l}\text { Nickle-bonded } \\
\text { titanium carbide }\end{array}$ & 67 & $\begin{array}{l}(867 \\
(1100)\end{array}$ & 6.3 & $\begin{array}{l}390 \\
(57)\end{array}$ & 0.23 & $\begin{array}{l}14 \\
(8.1)\end{array}$ & $\begin{array}{l}6.8 \\
(3.9)\end{array}$ & $\begin{array}{l}10.7 \\
(5.9)\end{array}$ & 1.4 \\
\hline Silicon nitride & 78 & $\begin{array}{l}\sim 1367 \\
(2000)\end{array}$ & $\begin{array}{l}3.11 \text { to } \\
3.24\end{array}$ & $\begin{array}{l}310 \\
(45)\end{array}$ & 0.26 & $\begin{array}{c}7.3 \\
(4.2)\end{array}$ & $\begin{array}{c}4.7 \\
(2.7)\end{array}$ & $\begin{array}{l}2.9 \\
(1.6)\end{array}$ & 1.7 \\
\hline $\begin{array}{l}\text { Bearing steel } \\
\text { (AISI M-50) }\end{array}$ & $\sim 63$ & $\begin{array}{l}>589 \\
(600)\end{array}$ & 7.6 & $\begin{array}{l}190 \\
(28)\end{array}$ & 0.28 & $\begin{array}{l}13.4 \\
(7.7)\end{array}$ & ---- & $\begin{array}{l}12.3 \\
(6.8)\end{array}$ & 1.1 \\
\hline
\end{tabular}

abased primarily on hardness retantion and test experience.

biased upon rolling-element fatigue testing. 
TABLE III. - RELATIVE LIFE ANO OYNAMIC CAPACITY OF HYBRID BEARING WITH VARIOUS ROLLING-ELEMENT MATERIALS

\begin{tabular}{|c|c|c|c|}
\hline $\begin{array}{l}\text { Raceway } \\
\text { material }\end{array}$ & $\begin{array}{l}\text { Rolling element } \\
\text { material }\end{array}$ & $\begin{array}{c}\text { Relative } \\
\text { life from } \\
\text { Ea. }(10){ }^{d} \\
\bar{L}_{H_{R}}\end{array}$ & $\begin{array}{l}\text { Relative } \\
\text { dynamie } \\
\text { capacity } \\
\text { to steel } \\
\text { from } \\
\text { Eq. (2), a } \\
n=9\end{array}$ \\
\hline \multirow[t]{6}{*}{ Steel } & $\begin{array}{l}\text { Crystallized } \\
\text { glass ceramlc }\end{array}$ & 18 & 2.6 \\
\hline & Alumina & 0.22 & 0.6 \\
\hline & sllicon carbide & 0.16 & 0.5 \\
\hline & $\begin{array}{l}\text { Nickle-bonded } \\
\text { titan } 1 \text { um carbide }\end{array}$ & 0.18 & 0.6 \\
\hline & stlicon nitride & 0.29 & 0.7 \\
\hline & Steel & 1 & 1 \\
\hline
\end{tabular}

abased upon fallure of steel raceway and assuming no fallure of roliting elements.

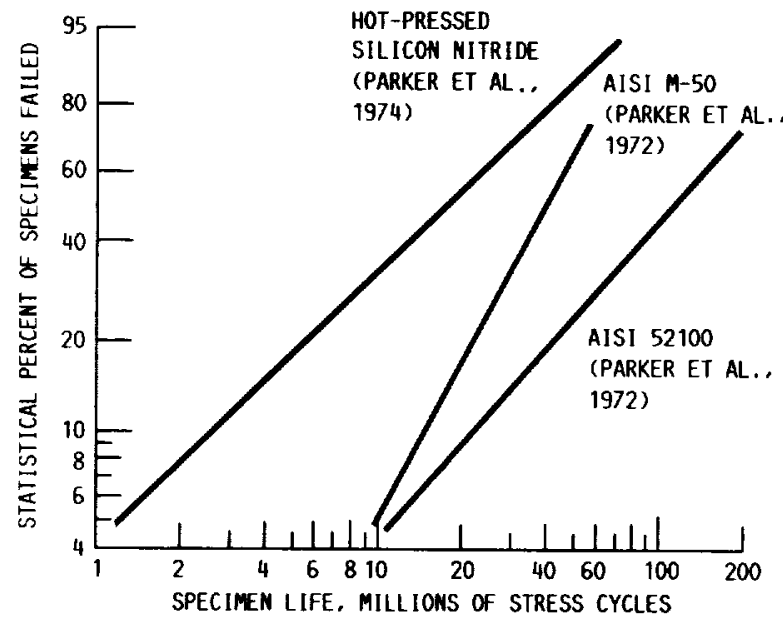

FIGURE 1， - ROLLING-ELEMENT FATIGUE LIFE OF HOTPRESSED SILICON NITRIDE BALLS AND STEEL BALLS IN FIVE-BALL FATIGUE TESTER. MAXIMUM HERTZ STRESS, $5.52 \times 10^{9} \mathrm{~N} / \mathrm{m}^{2}$ ( 800 000 PSI): SHAFT SPEED, $9400 \mathrm{RPM}$ : RACE TEMPERATURE, $328 \mathrm{~K}\left(130^{\circ} \mathrm{F}\right)$; CONTACT ANGLE, $30^{\circ}$ : LUBRICANT, SUPER-REFINED NAPHTHENIC MINERAL OIL. (PARKER ET AL.. 1974).

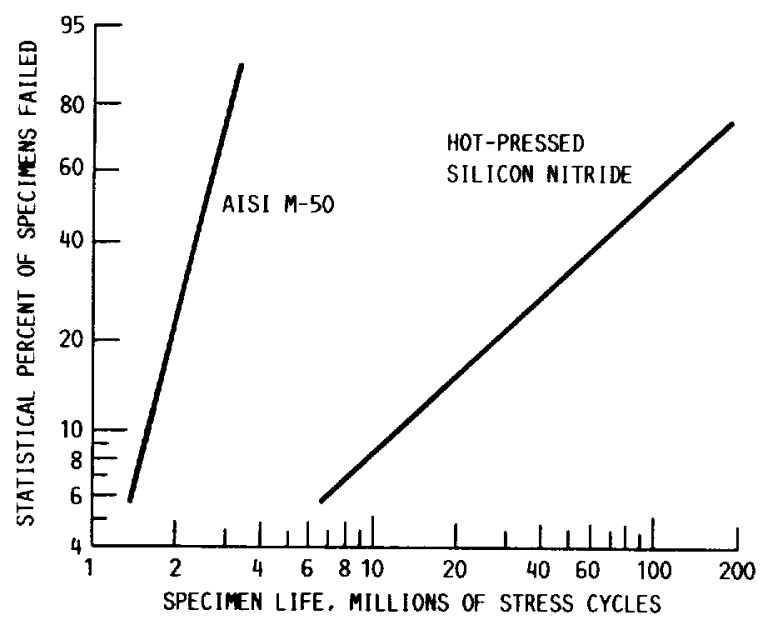

FIGURE 2. - ROLLING-ELEMENT FATIGUE LIFE OF HOTPRESSED SILICON MITRIDE ROLLERS IN ROLLING-CONTACT (R-C) FATIGUE TESTER, MAXIMUM HERTZ STRESS, $4.83 \times 10^{9} \mathrm{~N} / \mathrm{m}^{2}$ (800 000 PSI): ROLLER SPEED. 10000 RPM; TEMPERATURE, AMBIENT; LUBRICANT, TRIESTER (MIL-L-23699B)(BALMGARTNER ET AL., 1973), 


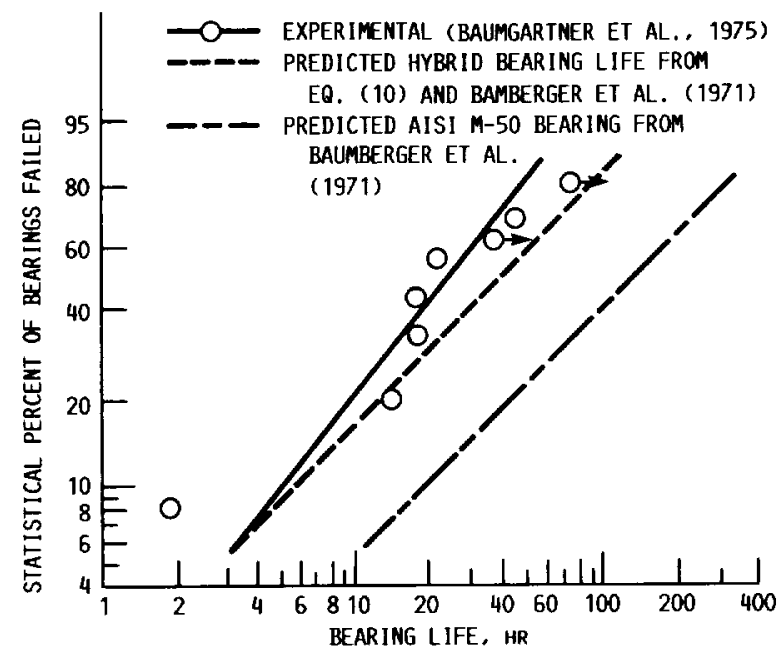

FIGURE 3. - COMPARISON OF THE EXPERIMENTAL AND PREEDITED LIVES OF HYBRID 57-MM BORE CYLINDRICAL ROLLER BEARING. RADIAL LOAD, 22464 N (5050 LB): MAXIMUM HERTZ STRESS, $2.82 \times 10^{9} \mathrm{~N} / \mathrm{M}^{2}$ (408 000 PSI); SHAFT SPEED, 5400 RPM : LUBRICANT TRIESTER; OUTER-RACE TEMPERATURE. $380 \mathrm{~K}\left(225^{\circ} \mathrm{F}\right)$.

EXPERIMENTAL LIFE

$1366 \mathrm{~K}\left(2000^{\circ} \mathrm{F}\right): \mathrm{MOS}_{2}$ LUBRICATION:

SHAFT SPEED, 450 RPM
$-044 \mathrm{~K}\left(700^{\circ} \mathrm{F}\right)$ : MINERAL-OIL LUBRICATION: SHAFT SPEED. 950 RPM - $300 \mathrm{~K}\left(80^{\circ} \mathrm{F}\right)$ : MINERAL-OIL

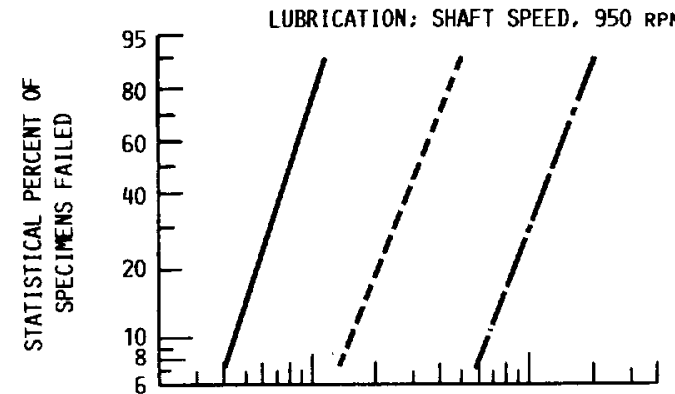

(A) LIFE DISTRIBUTION AT TEMPERATURE.

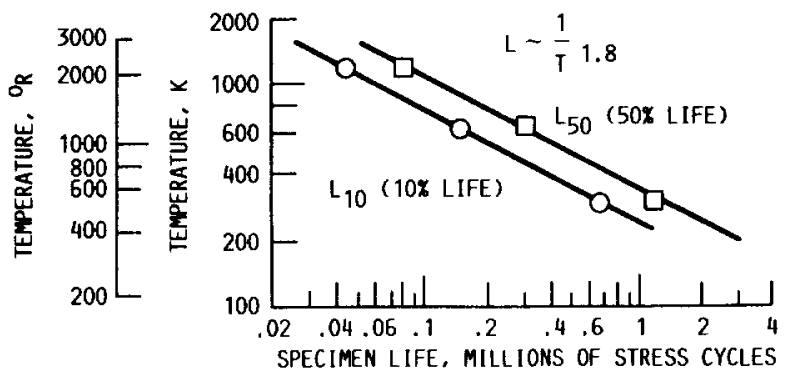

(B) EFFECT OF TEMPERATURE.

FIGURE 4. - ROLLING-ELEMENT FATIGUE LIFE OF HOT-PRESSED ALUMINA BALLS IN FIVE-BALL FATIGUE TESTER. MAXIMUM HERTZ STRESS. $3.39 \times 10^{9} \mathrm{~N} / \mathrm{m}^{2}$ (550 000 PSI); CONTACT ANGLE, $20^{\circ}$ (PARKER ET AL.. 1965). 


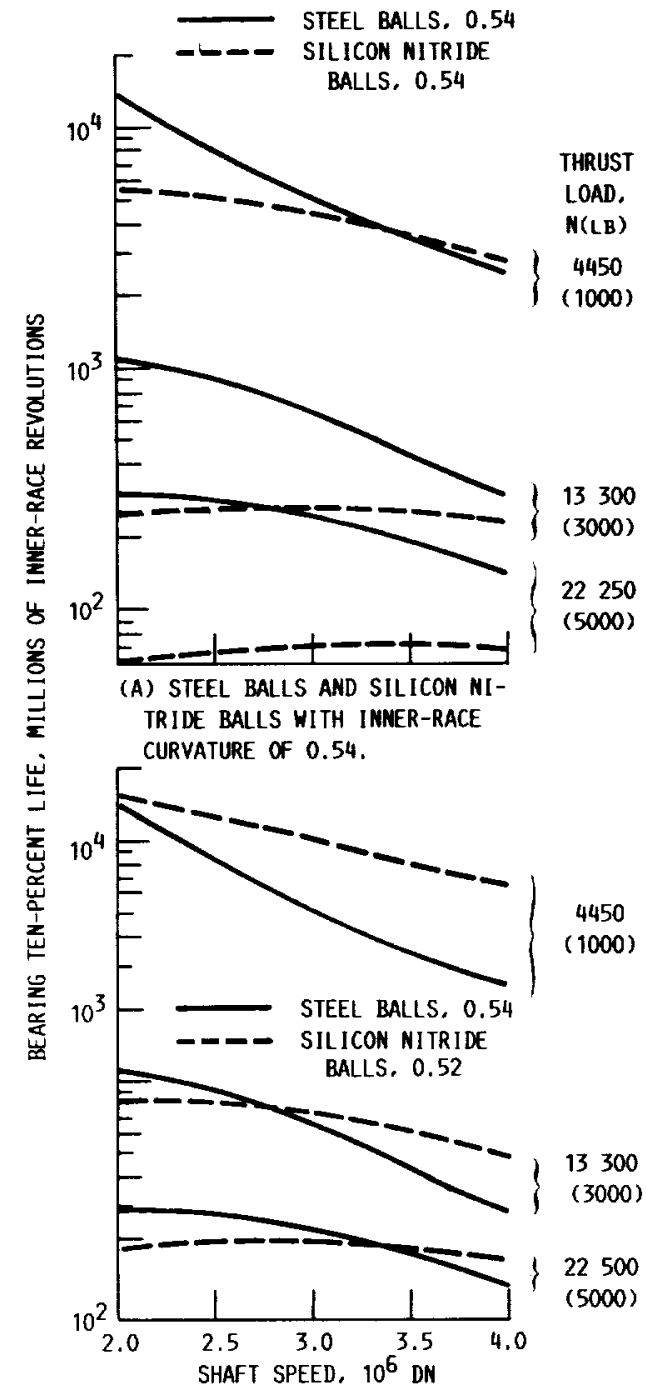

(B) STEEL BALLS AND SILICON NITRIDE BALLS WITH INNER-RACE CURVATURES OF 0.54 AND 0.52 . RESPECTIVELY.

FIGURE 5. - PREDICTED LIFE OF 120 MM BORE ANGULAR CONTACT BALL BEARING WITH SILICON NITRIDE BALLS BALL DIAMETER, $20.64 \mathrm{MM}$ (0.8125 IN.) (PARKER ET AL., 1975).
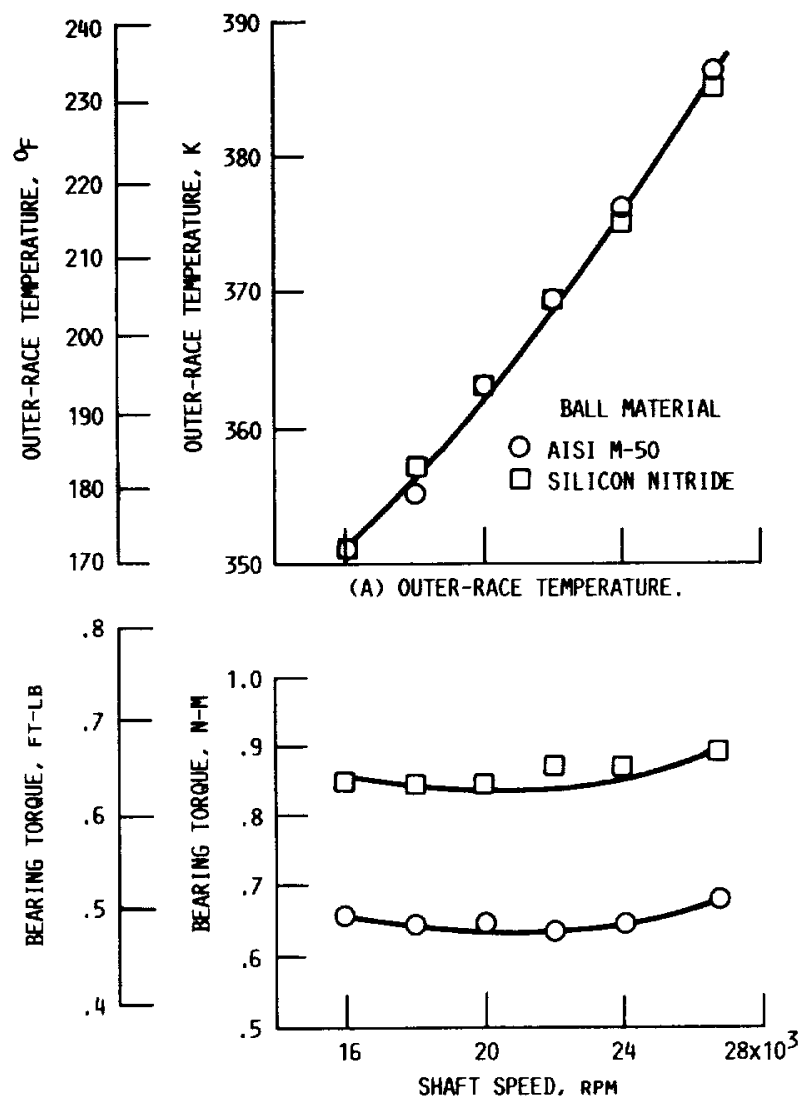

(B) BEARING TORQUE.

F1GURE 6. - PERFORMANCE OF 75 MM BORE ANGULAR-CONTACT BALL BEARING AS FUNCTION OF SHAFT SPEED. THRUST LOAD, $4400 \mathrm{~N}$ (989 LB). OIL FLOW RATE, 0.9 KG/MIN (2 LB/MIN) OIL INLET TEMPERATURE $316 \mathrm{~K}\left(109^{\circ} \mathrm{F}\right)$. 
BALL MATERIAL

\section{O AISI $M-50$}
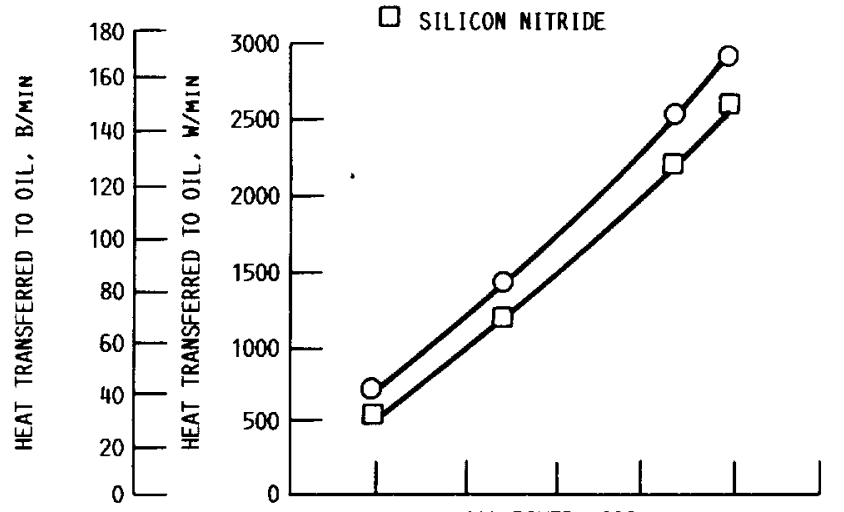

(A) POWER LOSS.

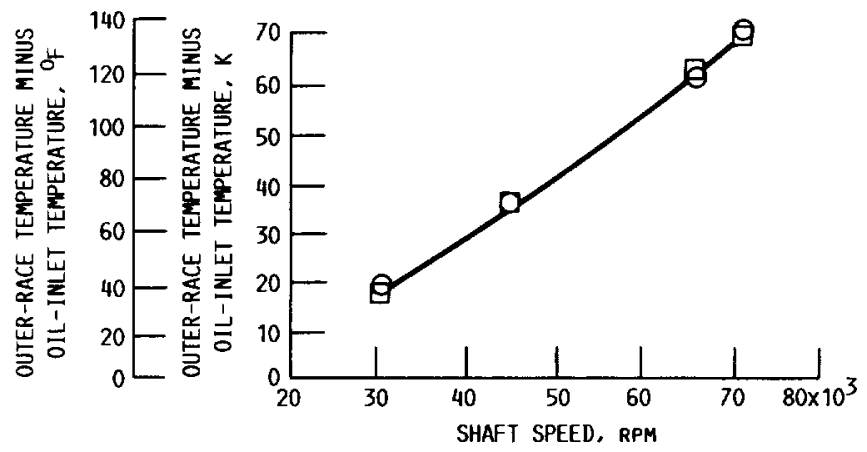

(B) OUTER-RACE TEMPERATURE.

FIGURE 7. - PERFORMANCE OF 35 MM BORE ANGULAR-CONTACT BALL BEARING AS A FUNCTION OF SHAFT SPEED. THRUST LOAD, $1200 \mathrm{~N}(270 \mathrm{LB})$ OIL FLOW RATE, $1.1 \mathrm{KG} / \mathrm{MIN}(2.5 \mathrm{LB} / \mathrm{MIN})$; OIL INLET TEMPERATURE, $399 \mathrm{~K}\left(150^{\circ} \mathrm{F}\right)$ (REDDECL IFF ET AL.. 1976).

\section{ORIGINAL PAGE IS \\ OF. POOR QUALITY}

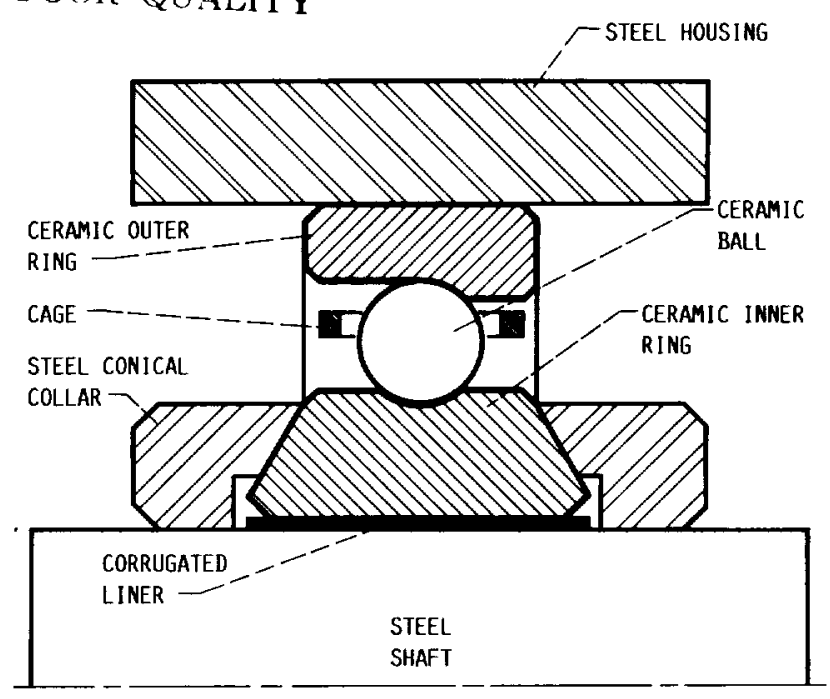

(A) MOUNTING ARRANGENENT.

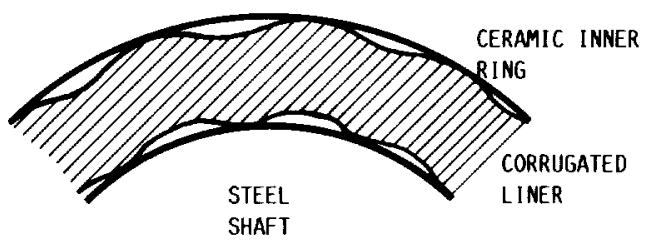

(B) CORRUGATED LINER.

FIGURE 8. - MOUNTING ARRANGEMENT OF FULL-COMPLIMENT CERAMIC BEARING ON A STEEL SHAFT, USING A CORRUGATED LINER (HOSANG, 1987).

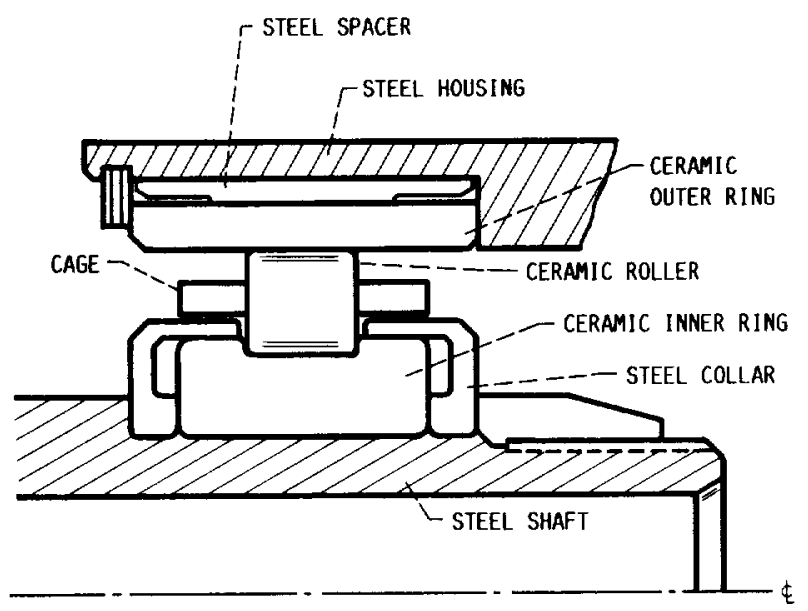

FIGURE 9. - MOUNTING ARRANGEMENT OF FULL-COMPL IMENT CERAMIC ROLLER BEARING ON A STEEL SHAFT, USING A STEEL COLLAR AND AND SPACER (BAILEY, 1983). 


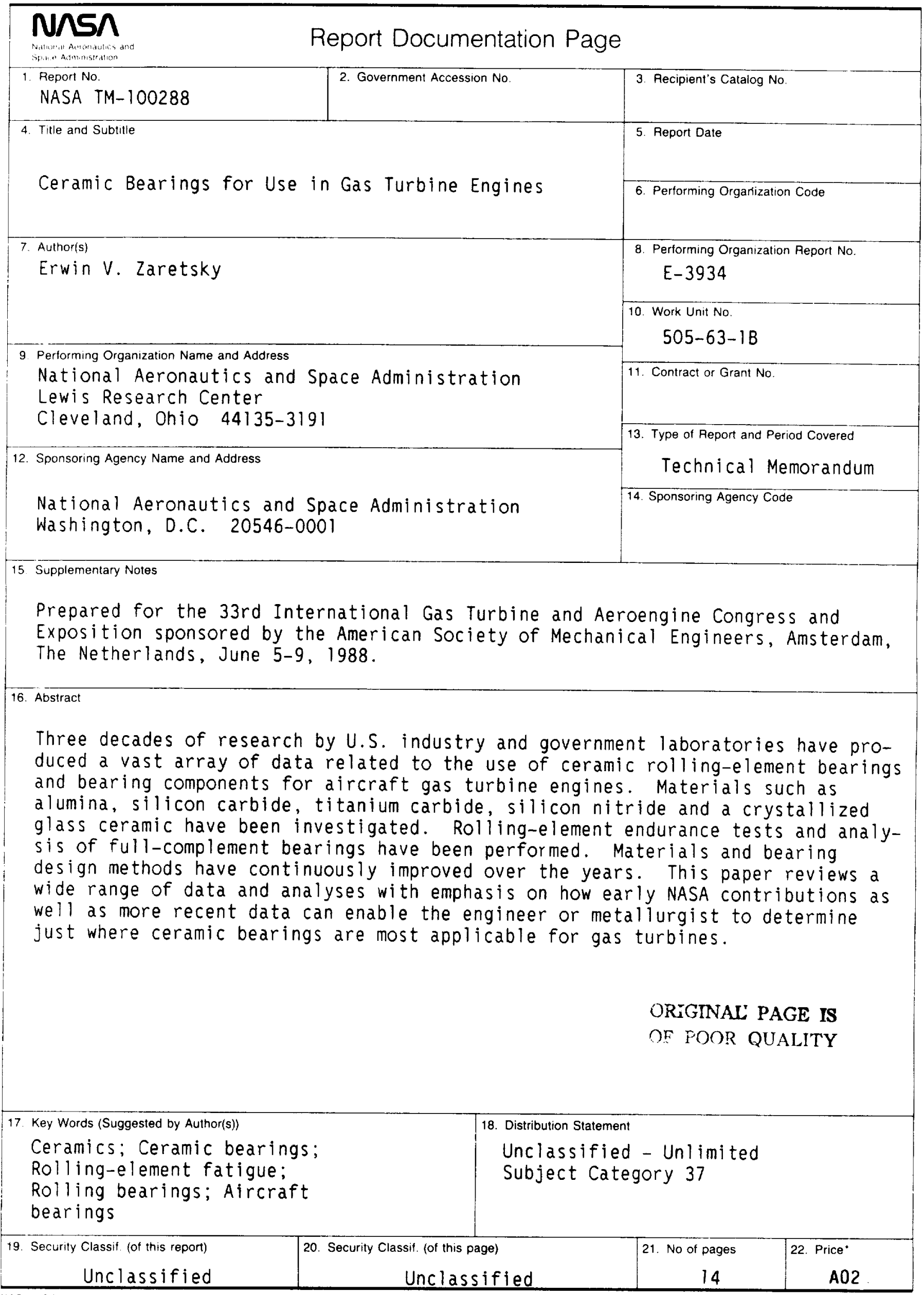

